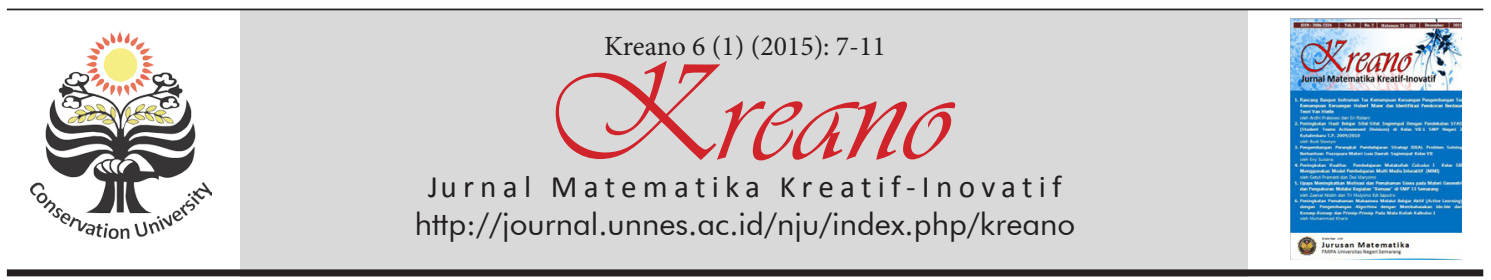

\title{
Perbedaan Hasil Belajar Siswa dalam Pendekatan Realistik dengan Pendekatan Ekspositori pada Mata Pelajaran Matematika Kelas IV SDN 101880 Tanjung Morawa
}

\author{
Daitin Tarigan' dan Esther M. Sinaga ${ }^{1}$ \\ 'Jurusan PGSD Universitas Negeri Medan \\ Email: daitin.tarigan@yahoo.co.id
}

DOI: http://dx.doi.org/10.15294/kreano.v6i1.4473

Received : 20 November 2015; Accepted: 27 November 2015; Published: Juni 2015

\begin{abstract}
Abstrak
Penelitian ini bertujuan untuk mengetahui perbedaan hasil belajar siswa dalam pendekatan realistik dengan pendekatan ekspositori pada mata pelajaran matematika kelas IV SDN 101880 Tanjung Morawa T.A. 2012/2013. Penelitian ini menggunakan metode kuasi eksperimen. Sampel yang diteliti sebanyak 60 siswa yang terdiri dari 25 siswa kelas eksperimen dan 35 siswa kelas kontrol. Instrumen yang di gunakan adalah tes hasil belajar bentuk isian sebanyak 10 soal. Berdasarkan analisis data pada kelas eksperimen diperoleh rata-rata nilai pre test 9,2 dan standar deviasi 12,88, untuk data post test diperoleh rata-rata 52 dan standar deviasi 31,36. Untuk kelas kontrol diperoleh rata-rata nilai pre test 15,14 dan standar deviasi 14,82, untuk data post test diperoleh rata-rata 44,57 dan standar deviasi 25,36 . Pengujian hipotesis menggunakan uji-t, didapat thitung $=5,38>$ ttabel $=1,671$, dengan taraf signifikansi $\alpha=0,05$. Maka Ho ditolak sehingga dapat disimpulkan bahwa Terdapat pebedaan hasil belajar matematika siswa pada materi penjumlahan pecahan yang diajarkan dengan pendekatan matematika realistik dan pendekatan ekspositori di kelas IV SD Negeri 101880 Tanjung Morawa tahun ajaran 2012/2013.
\end{abstract}

\begin{abstract}
This study aims to determine differences in student learning outcomes in a realistic approach to the expository approach in mathematics class IV SDN Tanjung Morawa 101880 TA 2012/2013. This study used a quasi-experimental methods. The samples studied were 60 students consisting of 25 students and 35 students experimental class control class. The instrument used is the achievement test stuffing form of 10 questions. Based on the analysis of data on the experimental class gained an average pre-test score of 9.2 and a standard deviation of 12.88 , post test data gained an average of 52 and a standard deviation of 31.36. To control class gained an average pre-test score standard deviation of 15.14 and 14.82, for a post test the data gained an average of 44.57 and a standard deviation of 25.36. Hypothesis testing using t-test, obtained $t=5.38>$ table $=1,671$, with a significance level $\alpha=0.05$. Then Ho is rejected so that it can be concluded that the learning outcomes are pebedaan mathematics student at the sum of material fractions being taught with realistic mathematics approach and expository approach in the fourth grade elementary school Tanjung Morawa 101880 2012/2013 academic year.
\end{abstract}

Keywords: learning outcomes, realistic approach, expository approach

\section{PENDAHULUAN}

Belajar adalah proses interaksi atau kegiatan yang dilakukan seseorang dengan lingkungannya untuk memperoleh perubahan kecakapan/pengetahuan, keterampilan dan sikap. Slameto (2010) mendefenisikan belajar ialah suatu proses usaha yang dilakukan seseorang yang dilakukan untuk memperoleh suatu pe- rubahan tingkah laku yang baru secara keseluruhan, sebagai hasil pengalamannya sendiri dalam interaksi dengan lingkungannya. Winkel (dalam Purwanto, 2011) mendefenisikan belajar adalah aktivitas mental/psikis yang berlangsung dalam interaksi aktif dengan lingkungan yang menghasilkan perubahanperubahan dalam pengetahuan, keterapilan 
dan sikap. Edwar Thorndike (dalam Sagala, 2009) berpendapat bahwa belajar adalah proses orang memperoleh berbagai kecakapan, keterampilan dan sikap.

Pembelajaran merupakan suatu proses dimana dalam lingkungan seseorang sengaja dikelola sehingga terjadi kerja sama antara guru dan siswa dalam menafaatkan potensi dan sumber yang ada. Baik dari dalam diri siswa maupun dari luar diri siswa yang digunakan untuk mencapai tujuan pendidikan. Corey (dalam Sagala, 2009) mengemukakan bahwa "konsep pembelajaran adalah suatu proses dimana lingkungan seseorang disengaja dikelola untuk memungkinkan ia turut serta dalam tingkah laku tertentu, pembelajaran merupakan subset khusus dari pendidikan." Sanjaya (2011) mengemukakan bahwa: "pembelajaran dapat diartikan sebagai proses kerja sama antara guru dan siswa dalam memanfaatkan segala potensi dan sumber yang ada baik potensi yang bersumber dari diri siswa itu sendiri seperti minat, bakat dan kemamampuan dasar yang dimiliki termasuk gaya belajar maupun potensi yang ada diluar diri siswa seperti lingkungan, sarana dan sumber belajar sebagi upaya untuk mencapai tujuan belajar tertentu."

Pelaksanaan pembelajaran perlu adanya lingkungan yang mampu menyediakan pengalaman belajar, menyediakan alternatif pengalaman belajar, mengintegrasikan pembelajaran dengan pengalaman siswa, mengintegrasikan pembelajaran yang dapat menjalin kerja sama antar siswa, memanfaatkan media pembelajaran, membuat pembelajaran lebih menarik sehingga siswa lebih berminat belajar dan tujuan pembelajaran dapat dicapai.

Menurut Hudojo (dalam Trianto, 2009) lingkungan belajar yang kondusif adalah lingkungan belajar yang 1) menyediakan pengalaman belajar yang mengaitkan pengetahuan baru dengan pengetahuan yang telah dimiliki siswa sehingga belajar merupakan proses pembentukan pengetahuan, 2) menyediakan berbagai alternatif pengalaman belajar, 3) mengintegrasikan pembelajaran dengan situasi realistik dan relevan dengan melibatkan pengalaman kongkrit, 4) mengintegrasikan pembelajaran yang memungkinkan terjadi interaksi dan kerja sama antara siswa, 5) memanfaatkan berbagai media agar pembelajaran lebih menarik, dan 6) melibatkan siswa secara emosional dan sosial sehingga pembelajaran lebih menarik dan siswa mau belajar.

Hasil belajar adalah perubahan yang terjadi setelah mengikuti proses belajar mengajar. Perubahan mengacu pada hasil belajar kognitif, afektif dan psikomotorik. Hasil belajar diukur untuk mengetahui pencapaian tujuan pendidikan.

Winkel (dalam Purwanto 2011) menyatakan bahwa hasil belajar adalah perubahan yang mengakibatkan manusia berubah dalam sikap dan tingkah lakunya. Aspek perubahan itu mengacu kepada taksonomi tujuan pengajaran yang dikembangkan oleh Bloom, Simpson dan Harrow mencakup aspek kognitif, afektif dan psikomotorik."

Hasil belajar merupakan realisasi tercapainya tujuan pendikan, sehingga hasil belajar yang diukur sangat tergantung kepada tujuan pendidikannya. Seperti yang dikemukakan oleh Purwanto (2011) menyebutkan bahwa hasil belajar adalah perubahan perilaku yang terjadi setelah mengikuti proses belajar mengajar sesuai dengan tujuan pendidikan.

Pendekatan matematika realistik adalah pendekatan yang lebih menekankan pada aktivitas siswa sehingga siswa menemukan sendiri konsep-konsep dari matematika itu sendiri (riyanto, et al., 2015). Pada pembelajaran realistik untuk menemukan konsep dari matematika tidak terpokus pada dunia nyata tetapi berdasarkan pengalaman, situasi dan menggunakan contoh-contoh yang dapat di bayangkan oleh siswa. (Prabowo, 2012)

Menurut Dian Armanto (dalam Manyatika, 2012) mengemukakan bahwa pendidikan matematika realistik adalah sebuah pendekatan pembelajaran matematika yang memfokuskan soal kontekstual sebagai aspek utamanya dalam memperkenalkan konsep dan prosedur matematika. Daitin Tarigan (2006) mengemukakah bahwa "Pandangan yang lain (berasal dari Prudenthal yang digunakan dalam PMRI) adalah sebagai kegiatan manusia yang lebih menekankan aktivitas siswa untuk mencari, menemukan dan membagun sendiri 
pengetahuan yang dia perlukan."

Dalam pendekatan ekspositori guru memiliki peran dominan seperti pendapat Sagala (2009) berpendapat bahwa pendekatan ekspositori merupakan pendekatan yang menempatkan guru sebagai pusat pengajaran, karena guru lebih aktif memberikan informasi, menerangkan suatu konsep, mendemonstasikan keterampilan dalam memperoleh pola, aturan, dalil, memberikan contoh soal beserta penyelesaiannya, memberi kesempatan siswa untuk bertanya, dan kegiatan guru lainnya.

Dalam pembelajaran ini diharapkan siswa dapat menangkap dan mengingat informasi yang telah diberikan oleh guru, serta mampu memberikan respons yang ia berikan pada saat diberikan pertanyaan oleh guru.

Dalam pendekatan ekspositori materi yang dipelajari sudah dikemas oleh guru menjadi materi jadi. Sehingga siswa tidak lagi dituntut untuk berpikir tentang cara mememukan pola, srtuktur, konsep dan lain lain melainkan menghafal materi yang diberikan oleh guru.Menurut Maruli Tambunan (2011) menjelaskan bahwa "pendekatan ekspositori merupakan pendekatan yang digunakan guru secara menyeluruh, lengkap dan sistematis dengan penyampaian verbal. Pendekatan ekspositori lebih mudah digunakan oleh guru namun kurang melibatkan siswa."

Jadi dalam hal ini dibutuhkan guru yang kreatif sehingga dalam memberikan informasi dan penjelasan kepada siswa menggunakan alat bantu berupa media seperti gambar, bagan, grafik, maupun yang lainnya. Sehingga siswa lebih cepat untuk mengingat dan memahami pembelajaran.

Berdasarkan pengalaman peneliti dilapangan selama PPL $85 \%$ hasil belajar matematika siswa kelas IV di SDN No. 101880 Tanjung Morawa tidak tuntas karena dibawah KKM dengan KKM 70,00.

Di dalam pembelajaran di kelas partisipasi siswa yang bersifat kontributif dan insiatif dalam pembelajaran masih sangat kurang. Siswa kurang dilibatkan dalam pembelajaran. Pada saat pembelajaran berlangsung siswa sering tidak memperhatikan guru mengajar dan siswa sering tidak menyelesaikan tugastugas dalam kelas. Dalam mengerjakan tugas di rumah banyak siswa yang tidak mengerjakannya.

Guru dalam menyampaikan pembelajaran matematika selalu menggunakan ceramah dan penugasan. Pemberian latihan atau tugas kepada siswa dapat mengasah kemampuannya. Tetapi, jika hanya ceramah dan pemberian tugas maka siswa akan bosan dan dia tidak suka dengan pelajaran matematika karena pembelajarannya yang itu-itu saja.

\section{METODE}

Penelitian ini menggunakan jenis penelitian eksperimen, yang menggunakan dua kelas yaitu kelas eksperimen dan kelas control. Variabel dalam penelitian ini adalah Variabel bebas: pengajaran yang menerapkan pembelajaran berdasarkan pendekatan matematika realistik dan pendekatan ekspositori. Variabel Terikat : Hasil belajar siswa dengan menggunakan pendekatan matematika realistik dan pendekatan ekspositori.

Populasi dalam penelitian ini. Populasi dalam penelitian ini adalah seluruh kelas IV SD Negeri 101880 Tanjung Morawa tahun 2012/2013 dengan jumlah 61 orang yang terdiri dari 2 kelas yakni kelas IVA dan kelas IVB. Sampel yang digunakan dalam penelitian ini adalaah sampel total atau sensus. Sesuai dengan pendapat Husaini Usman dan R. Purmono Setiady (2000) menyebutkan bahwa "penelitian yang menggunakan seluruh anggota populasinya disebut sampel total atau sensus. Penelitian ini berlaku jika anggota populasi relatif kecil." Teknik pengumpulan data pada penelitian ini adalah tes dan observasi. Data yang telah dikumpulkan akan dianalisis dengan tehnik pengumpulan data uji normalitas, uji homogenitas dan uji hipotesis.

\section{HASIL DAN PEMBAHASAN}

Berdasarkan temuan penelitian maka diperoleh:

\section{Uji normalitas}

Berdasarkan hasil pada Tabel 1, dapat disimpulkan bahwa data di kelas eksperimen dan kelas kontrol berdistribusi normal. Selanjutnya data dapat dianalisis dengan menggunakan statistika parametrik. 
Tabel 1. Hasil Uji Kenormalan

\begin{tabular}{lllll}
\hline No. & Kelas & $\mathrm{L}_{\text {hitung }}$ & $\mathrm{L}_{\text {tabel }}$ & Simpulan \\
\hline 1 & Eksperimen & 0,0533 & 0,175 & Normal \\
2 & Kontrol & 0,1443 & 0,1946 & Normal \\
\hline
\end{tabular}

Uii homogenitas

Dari hasil uji homogenitas diperoleh $\mathrm{F}_{\text {hitung }}=$ 1,53. Sedangkan $F_{\text {tabel }}$ dengan $\alpha=0,05$ maka $F_{\text {tabel }}$ adalah $F_{0,05(25-1,35-1)}=F_{0,05(24-1,34)}$ Dengan dk pembilang 24 dan dk penyebut 34. Maka $\mathrm{F}_{\text {tabel }}$ adalah 1,84. Dengan kriteria pengujian homogenitas $F_{\text {hitung }}=1,53<F_{\text {tabel }}=1,84$ maka dapat dinyatakan bahwa varians kedua kelas adalah homogen secara signifikan

\section{Uji hipotesis}

Dari hasil uji hipoetesis maka diperoleh $t_{\text {hitung }}$ adalah 5,38. Sedangkan harga $t_{\text {tabel }}$ diperoleh dari daftar distribusi t dengan $d k=\mathrm{n}_{1}+\mathrm{n}_{2}$ dan peluang (1- $\alpha$ ) dengan $\alpha=0,05$. Maka didapat $\mathrm{t}_{(1-\alpha)}$ dan $d k=25+35-2=58$, berada di antara dan $d k=40$ dan $d k=60$ atau $t_{(0,95)(58) .}$ Karena $t_{(0,95)(58)}$ tidak terdapat dalam daftar distribusi $t$, maka dapat diperoleh dengan interpolasi. Dan diperoleh $t_{\text {tabel }}=1,671$. Dengan membandingkan antar $t_{\text {hitung }}$ dengan $t_{\text {tabel }}$ maka $t_{\text {tabel }}=$ $5,38>t_{\text {tabel }}=1,671$.

Penelitian ini diawali dengan memberikan pretest terhadap kedua kelass sampel dengan test hasil belajar 10 soal dalam bentuk isian yaitu pada kelas eksperimen dan kelas kontrol. Pada kelas eksperimen sebelum diberikan perlakuan nilai rata-rata pre test 9,2 dan pada kelas kontrol 15,14.

Setelah diberikan perlakuan yang berbeda pada kedua kelas sampel, diperoleh nilai rata-rata dikelas ekperimen 52 dan dikelas kontrol adalah 44,57. Kemudian dilakukan uji normalitas pada kedua kelas sampel. Pada kelas eksperimen diperoleh $L_{\text {hitung }}=0,0533<L_{\text {tabel }}=0,175$. Dan pada kelas kontrol diperoleh $L_{\text {hitung }}=0,1443<L_{\text {tabel }}$ $=0,1496$. Maka dapat disimpulkan bahwa kedua kelas sampel berdistribusi normal. Selanjutnya dilakukan uji homogenitas, maka diperoleh $F_{\text {hitung }}=1,53<F_{\text {tabel }}=1,84$ maka dapat dinyatakan bahwa varians kedua kelas adalah homogen.

Selanjutnya untuk mengetahui apakah benar-benar ada perbedaan yang signifikan secara statistik maka dilakukan pengujian terhadap hipotesis. Berdasarkan hasil pengujian hipotesis pada lampiran yang menggunakan uji t diperoleh $t_{\text {hitung }}=5,38>t_{\text {tabel }}=1,671$. Sehingga dapat diperoleh kesimpulan bahwa Terdapat pebedaan hasil belajar matematika siswa pada materi penjumlahan pecahan yang diajarkan dengan pendekatan matematika realistik dan pendekatan ekspositori di kelas IV SD Negeri 101880 Tanjung Morawa tahun ajaran 2012/2013.

Dari hasil observasi siswa dalam kegiatan pembelajaran mengalami peningkatan yang positif pada kelas eksperimen pada pertemuan I dan II yaitu dengan rata-rata 65,3 dengan menggunakan pendekatan matematika realistik membuat ssiswa lebih aktif. Pada kelas kontrol pada pertemuan I dan II yaitu dengan rata-rata 60,8 Sehingga dapat diperoleh kesimpulan bahwa terdapat perbedaan akibat pendekatan pembelajaraan matematika realistik terhadap hasil belajar siswa pada materi pecahan di kelas IV SD Negeri 101880 Tanjung Morawa tahun ajaran 2012/2013.

\section{SIMPULAN}

Berdasarkan penelitian dapat disimpulkan bahwa: (1) Rata-rata pre test kelas ekperimen sebelum diberikan perlakuan adalah 9,2 dan setelah diberikan perlakuan dengan menggunakan pendekatan matematika realistik diperoleh hasil belajar siswa (post test) rata-rata hasil belajar siswa adalah 52. Menunjukkan adanya peningkatan hasil belajar siswa setelah diberikan perlakuan dengan pendekatan matematika realistik; (2) Rata-rata pre test kelas kontrol sebelum diberikan perlakuan adalah 15,14 dan setelah diberikan perlakuan dengan menggunakan pendekatan matematika realistik diperoleh hasil belajar siswa (post test) rata-rata hasil belajar siswa adalah 44,57. Menunjukkan adanya peningkatan hasil belajar siswa setelah diberikan perlakuan dengan pendekatan ekspositori; (3) Terdapat pebedaan hasil belajar matematika siswa pada materi penjumlahan pecahan yang diajarkan dengan pendekatan matematika realistik dan pendekatan ekspositori. Dengan hasil belajar matematika siswa yang diajarkan dengan menggunakan pendekatan memberikan hasil yang lebih tinggi dibandingkan dengan pendekatan ekspositori. 
Berdasarkan hasil penelitian ini, maka penulis mengajukan beberapa saran sebagai berikut: (1) Dalam proses matematika guru diharapkan menggunakan pendekatan matematika realistik sebagai salah satu pembelajaran matematika untuk meningkatkan proses pembelajaran dan pencapaian maksimal peserta didik dalam memahami konsep-konsep matematika; (2) Diharapkan kepada guru perlu meningkatkan kemampuan dan keterampilan dalam bentuk penguasaan ragam metode dan ragam media guna membangkitkan minat dan perhatian siswa dalam pelajaran matematika, belajar matematika menjadi menarik bagi siswa dan menyenangkan; (3) Kepala sekolah diharapkan memfasilitasi media pembelajaran matematika guna mempelancar proses pembelajaran matematika agar tercapai tujuan pembelajaran yang diharapkan; (4) Pengawas Pendidikan diharapkan memberikan pelatihan-pelatihan kepada guru-guru, yang dapat membatu mereka di dalam menciptakan inovasi-inovasi pembelajaran; dan (5) Bagi peneliti lain yang berminat menggunakan pendekataan matematika realistik dalam pembelajaran matematika, diharapkan dapat mengembangkan lebih lanjut terhadap materi dalam pembelajaran matematika Sekolah Dasar.

\section{DAFTAR PUSTAKA}

Mayantika, S. (2012). Upaya Meningkatkan Hasil Belajar Siswa Melalui Pendekatan Matematika Realistik Pada Pokok Bahasan Penjumlahan Dan Pegurangan Pecahan Di Kelas V Min Sei Agul Medan T.A 2011/2012. Skripsi. FMIPA Unimed.

Prabowo, A. (2012). Pembelajaran Berbasis Proyek Untuk Meningkatkan Pemahaman Mahasiswa atas Permasalahan Statistika pada Perkuliahan Studi Kasus dan Seminar. Kreano, Jurnal Matematika Kreatif-Inovatif, 3(2), 82-90.

Purwanto. (2011). Evaluasi hasil Belajar. Yogyakarta: Pustaka pelajar.

Riyanto, et al. (2015). Keefektivan PMRI Berbantuan Alat Peraga Terhadap Kemampuan Pemecahan Masalah Serupa PISA Pada Kelas VII. Kreano, Jurnal Matematika Kreatif-Inovatif, 5(1), 33-40.

Sagala, S. (2009). Konsep dan Makna Pembelajaran. Bandung: Alvabet.

Sanjaya, W. (2011). Perencanaan dan Desain Sistem Pembelajaran. Jakarta: Kencana Prenada Media Group.

Slameto. (2010). Belajar dan faktor-faktor yang Mempengaruhi. Jakarta: Rineka Cipta.

Tambunan, M. (2011). Perbedaan Hasil Belajar Matematika Siswa Yang Diajarkan Menggunakan Metode Pembelajaran Matematika Realistik Dengan Metode Ekspositori Dikelas VIII SMP Swasta Teladan Medan Tahun Ajaran 2011/2012. Skripsi. FMIPA. Unimed.

Tarigan, D. (2006). Pembelajaran Matematika Realistik. Jakarta: Departemen Pendidikan Nasional.

Trianto. (2009). Mendesain Model Pembelajaran Inovatif-Progresif. Jakarta: Kencana Predana Media Group.

Usman, H dan R.P. Setiady. (2000). Pengantar Statistika. Jakarta: Bumi Aksara. 